\title{
EFFECT OF INORGANIC NUTRIENT POLLUTANTS ON OVIPOSITION PREFERENCE, EGG HATCHING RATE AND LARVAL DEVELOPMENT OF CULEX QUINQUEFASCIATUS
}



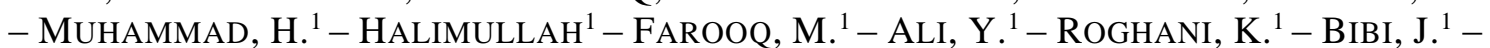 \\ KHAN, S. ${ }^{1}-$ MEHMOOD, A. ${ }^{1}$ \\ ${ }^{I}$ Department of Zoology, University of Malakand \\ Chakdara, Dir Lower, Khyber Pakhtunkhwa, Pakistan \\ ${ }^{2}$ Department of Zoology, Islamia College Peshawar \\ Peshawar, Khyber Pakhtunkhwa, Pakistan \\ ${ }^{3}$ Department of Biotechnology, University of Malakand \\ Chakdara, Dir Lower, Khyber Pakhtunkhwa, Pakistan \\ *Corresponding author \\ e-mail:ikramilahi@uom.edu.pk
}

(Received $30^{\text {th }}$ Jan 2019; accepted $21^{\text {st }}$ Mar 2019)

\begin{abstract}
The present research aims to evaluate the effects of ammonium $\left(\mathrm{NH}_{4}^{+}\right)$, nitrate $\left(\mathrm{NO}_{3}{ }^{-}\right)$and phosphate $\left(\mathrm{PO}_{4}^{-3}\right)$ on oviposition preference, hatching rate, time to pupation, pupation rate, time to adult emergence, adult emergence rate and female to male ratio of Culex quinquefasciatus mosquito, under laboratory conditions. The mosquito preferred to oviposit in containers containing $5 \mathrm{ppm} \mathrm{NH}_{4}{ }^{+}, 45 \mathrm{ppm}$ $\mathrm{NO}_{3}{ }^{-}$or $30 \mathrm{ppm} \mathrm{PO}_{4}{ }^{-3}$ solution. No significant effect of these polutants on egg hatching rate was


solution reached earlier to pupal and adult stages. The presence of $\mathrm{NH}_{4}{ }^{+}(5 \mathrm{ppm}), \mathrm{NO}_{3}{ }^{-}(45 \mathrm{ppm})$ or $\mathrm{PO}_{4}{ }^{-3}$ $(30 \mathrm{ppm})$ in aqueous medium, resulted in decreased time to pupation or adult emergence and increased pupation and adult emergence rates. The adults emerged from these larvae showed significantly higher female to male ratio as compared to control adults $(\mathrm{P}<0.05)$. From the findings of the present research, it is concluded that the levels of $\mathrm{NH}_{4}{ }^{+}, \mathrm{NO}_{3}{ }^{-}$or $\mathrm{PO}_{4}{ }^{-3}$ set in effluents for wastewater reuse in agricultural irrigation by WHO (2006) are favorable for the survival and development of $C x$. quinquefasciatus mosquito, however higher levels of $\mathrm{NH}_{4}{ }^{+}, \mathrm{NO}_{3}{ }^{-}$or $\mathrm{PO}_{4}{ }^{-3}$ are not favorable for the survival and development of this mosquito. These results help in identification of concentration ranges of the ammonium, nitrate and phosphate that make the larval habitat favorable for survival and reproduction of Culex mosquitoes. This could be helpful in effective control of mosquito borne diseases.
\end{abstract}

Keywords: oviposition preference, hatching rate, pupation rate, time to pupation, emergence rate, time to adult emergence, female to male ratio

\section{Introduction}

Mosquito larval habitats are influenced by many physical, chemical and biological factors. The results of several studies have shown the relationship between habitat characteristics and mosquito larval abundance and distribution (Kenea et al., 2011). Ammonium $\left(\mathrm{NH}_{4}{ }^{+}\right)$, nitrate $\left(\mathrm{NO}_{3}{ }^{-}\right)$and phosphate $\left(\mathrm{PO}_{4}^{-3}\right)$ are the well-known inorganic nutrient pollutants of water bodies. The $\mathrm{NH}_{4}{ }^{+}, \mathrm{NO}_{3}{ }^{-}$and other ionic forms of inorganic nitrogen enter the surface water bodies both from natural and anthropogenic sources (Wetzel, 2001; Rabalais, 2002). Phosphate is also an important inorganic nutrient in aquatic ecosystem and surface water receives it from various 
sources such as agricultural use of fertilizers, domestic and industrial wastewater, and atmospheric deposition (Tchobanoglous and Burton, 1991; Grubb et al., 2000).

The inorganic nutrient pollutants such as $\mathrm{NH}_{4}{ }^{+}, \mathrm{NO}_{3}{ }^{-}$and $\mathrm{PO}_{4}{ }^{-3}$ in mosquito breeding sites influences the development of mosquito larvae (Noori et al., 2015). Breeding sites with higher $\mathrm{NH}_{4}{ }^{+}, \mathrm{NO}_{3}{ }^{-}$and $\mathrm{PO}_{4}{ }^{-3}$ concentration provide better microbial food source for mosquito larvae (Dowling et al., 2013). Knowledge of mosquito breeding habitats is useful for identifying the most productive water bodies in a given area and developing efficient control approaches (Noori et al., 2015). Noori et al. (2015) designed a mesocosm experiment for investigating the relationships between inorganic nutrient pollutants (i.e., $\mathrm{NH}_{4}{ }^{+}, \mathrm{NO}_{3}{ }^{-}$and $\mathrm{PO}_{4}{ }^{-3}$ ) concentrations and larval development of $C x$. quinquefasciatus. High concentrations of nitrate and phosphate favored the larval development and survival rates. High $\mathrm{NO}_{3}{ }^{-}$concentration suppressed the development of female mosquito but favored the development of male mosquitoes. The adult mosquitoes which emerged in high $\mathrm{NO}_{3}{ }^{-}$concentration solution were found to be faster in development. It was further observed that in the absence of $\mathrm{NO}_{3}{ }^{-}$, the addition of $\mathrm{PO}_{4}{ }^{-3}$ slow the larval development. Schletzbaum (2013), evaluated the influence of water nutrient pollutant on the sequence of larval hatching of two mosquito species, Culex pipiens and Anopheles albopictus in container habitats. Higher $\mathrm{NO}_{3}{ }^{-}$concentration in the larval environment resulted in larger Anopheles albopictus females and higher emergence rate and shorter time to emergence for Culex pipiens.

Increased level of different forms of inorganic nitrogen in water is toxic to fresh water invertebrates, fishes and amphibian (Hickey and Vickers, 1994; Camargo et al., 2005). Phosphate $\left(\mathrm{PO}_{4}^{-3}\right)$ toxicity with aquatic invertebrates has also been reported (Kim et al., 2013). According to Williams et al. (1986), the elevated levels of nitrates, ammonia and phosphorus in the surface waters (in both marine and fresh water), can affect invertebrate diversity in feeding grounds. According to the compendium of standards for wastewater reuse in the Eastern Mediterranean region, the maximum permissible concentrations of $\mathrm{NH}_{4}{ }^{+}, \mathrm{NO}_{3}{ }^{-}$and $\mathrm{PO}_{4}{ }^{-3}$ in effluents for reuse in agricultural irrigation are 5, 45 and $30 \mathrm{ppm}$, respectively (WHO, 2006). Irrigation water for agriculture has the potential to create mosquito breeding habitats within the storage system for water along the water supplying channels or in the field that receive water.

Monitoring of pollutants in aquatic environment is necessary for investigating the status of pollution in such environment for protection of human life and wildlife. From environmental, ecological and economic point of view, regular assessment of the pollutant levels and their destiny in different media of environment is essential. Regulation and re-evaluation of the threshold levels of different pollutants set by different international and national organizations is very important. The present research aims to evaluate the effects of threshold levels of three inorganic nutrient pollutants $\left(\mathrm{NH}_{4}{ }^{+}, \mathrm{NO}_{3}{ }^{-}\right.$and $\left.\mathrm{PO}_{4}{ }^{-3}\right)$ set by WHO (2006) compendium of standards for wastewater reuse in agricultural irrigation in the Eastern Mediterranean region on the life-history of a common and economically important insect (Culex quinquefasciatus Say, 182) in water under laboratory conditions. The study contributes to the science of the effects of increasing level of inorganic nutrient pollutants on insect populations. 


\section{Materials and methods}

During the present research, the effects of $\mathrm{NH}_{4}{ }^{+}, \mathrm{NO}_{3}{ }^{-}$and $\mathrm{PO}_{4}{ }^{-3}$ on oviposition preference, hatching rate and larval development of Culex quinquefasciatus (Say, 182) were studied in laboratory condition. During larval development, the effects of above inorganic nutrient pollutants on time to pupation, pupation rate, time till first appearance of adult, adult emergence rate, and female to male ratio were studied.

\section{Required chemicals}

The chemicals used included ammonium chloride $\left(\mathrm{NH}_{4} \mathrm{Cl}\right)$ of Merck Co. (Darmstadt, Germany) for $\mathrm{NH}_{4}{ }^{+}$, sodium nitrate $\left(\mathrm{NaNO}_{3}\right)$ of Sigma-Aldrich (USA) for $\mathrm{NO}_{3}{ }^{-}$and sodium phosphate dibasic $\left(\mathrm{Na}_{2} \mathrm{HPO}_{4}\right)$ of Sigma-Aldrich (USA) for $\mathrm{PO}_{4}{ }^{-3}$. The following are the detail of molar mass of the compounds and the related ions used during the present research:

- Ammonium chloride $\left(\mathrm{NH}_{4} \mathrm{Cl}\right)$ molar mass is $53.5 \mathrm{~g}$ and contains $18 \mathrm{~g} \mathrm{of} \mathrm{NH}_{4}^{+}$.

- Sodium nitrate $\left(\mathrm{NaNO}_{3}\right)$ molar mass is $85.5 \mathrm{~g}$ and contains $62 \mathrm{~g}$ of $\mathrm{NO}_{3}{ }^{-1}$.

- Sodium phosphate dibasic $\left(\mathrm{Na}_{2} \mathrm{HPO}_{4}\right)$ molar mass is $144 \mathrm{~g}$ and contains $97 \mathrm{~g}$ of $\mathrm{PO}_{4}{ }^{-3}$.

\section{Preparation of solutions}

Initially $1000 \mathrm{ppm}$ stock solution of each pollutant was prepared. For preparation of stock solution of $1000 \mathrm{ppm}(1000 \mathrm{mg} / \mathrm{L})$ of $\mathrm{NH}_{4}{ }^{+}, 2.9$ gram of $\mathrm{NH}_{4} \mathrm{Cl}$ was required. For preparation of stock solution of $1000 \mathrm{ppm}(1000 \mathrm{mg} / \mathrm{L})$ of $\mathrm{NO}_{3}{ }^{-}, 1.4$ gram of $\mathrm{NaNO}_{3}$ was required. For preparation of stock solution of $1000 \mathrm{ppm}(1000 \mathrm{mg} / \mathrm{L})$ of $\mathrm{PO}_{4}{ }^{-3}$, 1.5 gram of $\mathrm{Na}_{2} \mathrm{HPO}_{4}$ was required.

\section{Laboratory rearing of Cx. quinquefasciatus}

Experiments were conducted on the effects of $\mathrm{NH}_{4}^{+}, \mathrm{NO}_{3}{ }^{-1}$ and $\mathrm{PO}_{4}^{-3}$ on larval mortality, egg laying preference, egg hatching rate and larval development of $C x$. quinquefasciatus. Laboratory colonies of $C x$. quinquefasciatus were maintained during April and May 2016.

\section{Laboratory conditions}

The experiments were conducted during April and May 2016. Inside the laboratory, minimum temperature was $\geq 20^{\circ} \mathrm{C}$ and maximum temperature was $\leq 33^{\circ} \mathrm{C}$. The laboratory was wide, well ventilated and receiving sun light at the day time through glass windows.

\section{Bioassay for effect of inorganic nutrient pollutants on oviposition preference}

According to the standards for wastewater reuse in the Eastern Mediterranean Region, the maximum permissible concentrations of $\mathrm{NH}_{4}{ }^{+}, \mathrm{NO}_{3}{ }^{-1}$ and $\mathrm{PO}_{4}{ }^{-3}$ in effluents for reuse in agricultural irrigation are 5, 45 and $30 \mathrm{ppm}$, respectively (WHO, 2006). Irrigation water for agriculture has the potential to create mosquito breeding habitats within the storage system for water along the water supplying channels or in the field that receive water. The present study aimed to investigate the effect of $\mathrm{NH}_{4}{ }^{+}, \mathrm{NO}_{3}{ }^{-1}$ and $\mathrm{PO}_{4}{ }^{-3}$ on oviposition preference of $C x$. quinquefasciatus at the concentrations which are permissible in effluents for reuse in agricultural irrigation (WHO, 2006). The effect of 
$\mathrm{NH}_{4}^{+}, \mathrm{NO}_{3}^{-1}$ and $\mathrm{PO}_{4}^{-3}$ on oviposition preference of $C x$. quinquefasciatus was also studied at concentrations higher than WHO recommended concentrations of these nutrient pollutants in effluents for reuse in agricultural irrigation (WHO, 2006). Thus, two concentrations of $\mathrm{NH}_{4}^{+}$(5 and $\left.10 \mathrm{ppm}\right), \mathrm{NO}_{3}{ }^{-1}$ (45 and $\left.90 \mathrm{ppm}\right)$ and $\mathrm{PO}_{4}^{-3}$ (30 and $60 \mathrm{ppm}$ ) were tested for their effect on oviposition preference of $C x$. quinquefasciatus gravid female adult. The main purpose was to investigate the effect of $\mathrm{NH}_{4}{ }^{+}, \mathrm{NO}_{3}{ }^{-1}$ and $\mathrm{PO}_{4}{ }^{-3}$ on oviposition preference of $C x$. quinquefasciatus at concentrations which are permissible in effluents for reuse in agricultural irrigation (WHO, 2006). Three mosquito cages (cage 1-3) were used during this experiment (Figure 1).

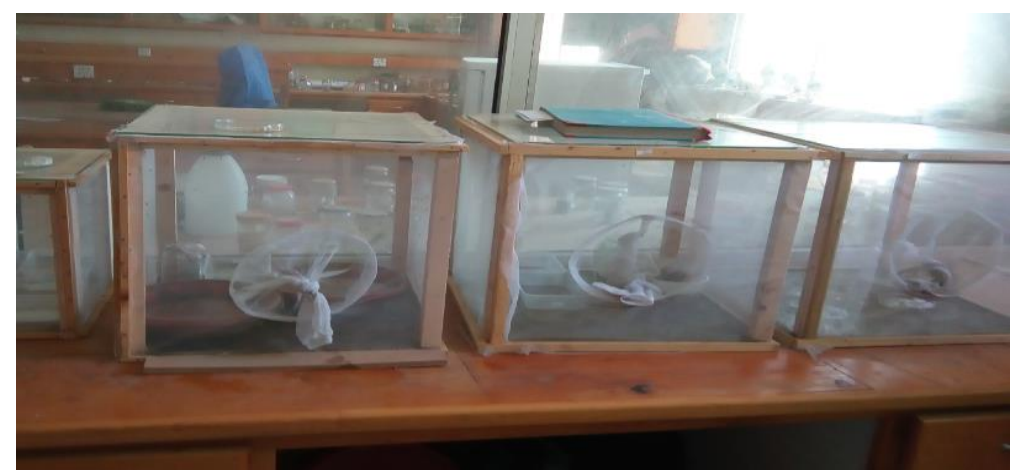

Figure 1. Picture showing mosquito cages used during the present research

During the study of effect of $\mathrm{NH}_{4}{ }^{+}$on oviposition preference of $C x$. quinquefasciatus gravid female adult, two $\mathrm{NH}_{4}{ }^{+}$solutions of 5 and $10 \mathrm{ppm}(300 \mathrm{ml}$ each) in two $400 \mathrm{ml}$ polyethylene containers were placed in mosquito cage $(45 \mathrm{~cm} \times 45 \mathrm{~cm} \times 45 \mathrm{~cm})$. In addition, a control polyethylene container containing $300 \mathrm{ml}$ non-chlorinated tap water was also placed inside the mosquito cage along with $\mathrm{NH}_{4}{ }^{+}$solution. For studying the effect of $\mathrm{NO}_{3}{ }^{-1}$ on oviposition preference, two $\mathrm{NO}_{3}{ }^{-1}$ solutions of 45 and $90 \mathrm{ppm}$ (300 ml each) in two $400 \mathrm{ml}$ polyethylene containers were placed in mosquito cage. In addition, a control polyethylene container containing $300 \mathrm{ml}$ non-chlorinated tap water was also placed inside the mosquito cage along with $\mathrm{NO}_{3}{ }^{-1}$ solution. For studying the effect of $\mathrm{PO}_{4}{ }^{-3}$ on oviposition preference, two $\mathrm{PO}_{4}{ }^{-3}$ solutions of 30 and $60 \mathrm{ppm}$ (300 $\mathrm{ml}$ each) in two $400 \mathrm{ml}$ polyethylene containers were placed in a mosquito cage. In addition, a control polyethylene container containing $300 \mathrm{ml}$ non-chlorinated tap water was also placed inside the mosquito cage along with $\mathrm{PO}_{4}{ }^{-3}$ solution. The experiment was run in triplicate.

For each mosquito cage, 100 blood fed and gravid female adult mosquitoes ( 5 days of age after emergence from pupae) were caught from the existing laboratory colony of $C x$. quinquefasciatus through mouth aspirator and then introduced into the cage. The gravid female mosquitoes laid egg into the containers after 2 or 3 days of introduction. The number of egg rafts laid by female mosquitoes in each jar was counted under stereo binocular microscope with digital camera (Labomed Inc, USA) so that to determine the effect of inorganic nutrient pollutants on the egg laying preference of $C x$. quinquefasciatus female adult mosquitoes. Schematic of experiment on the effect of inorganic nutrient pollutants on oviposition preference and egg hatching rate is shown in Figure 2. Egg rafts and eggs within rafts have been shown in Figures 3-4. 


$$
\text { - } 10529 \text { - }
$$

\section{Bioassay for effect of inorganic nutrient pollutants on egg hatching rate}

The egg rafts laid by the gravid female mosquitoes during oviposition assays for $\mathrm{NH}_{4}{ }^{+}, \mathrm{NO}_{3}{ }^{-}$and $\mathrm{PO}_{4}{ }^{-3}$, hatched into first instar larvae. After two days of hatching, all the containers were brought out of the mosquito cages and the total number of eggs and the number of hatched out larvae were counted.

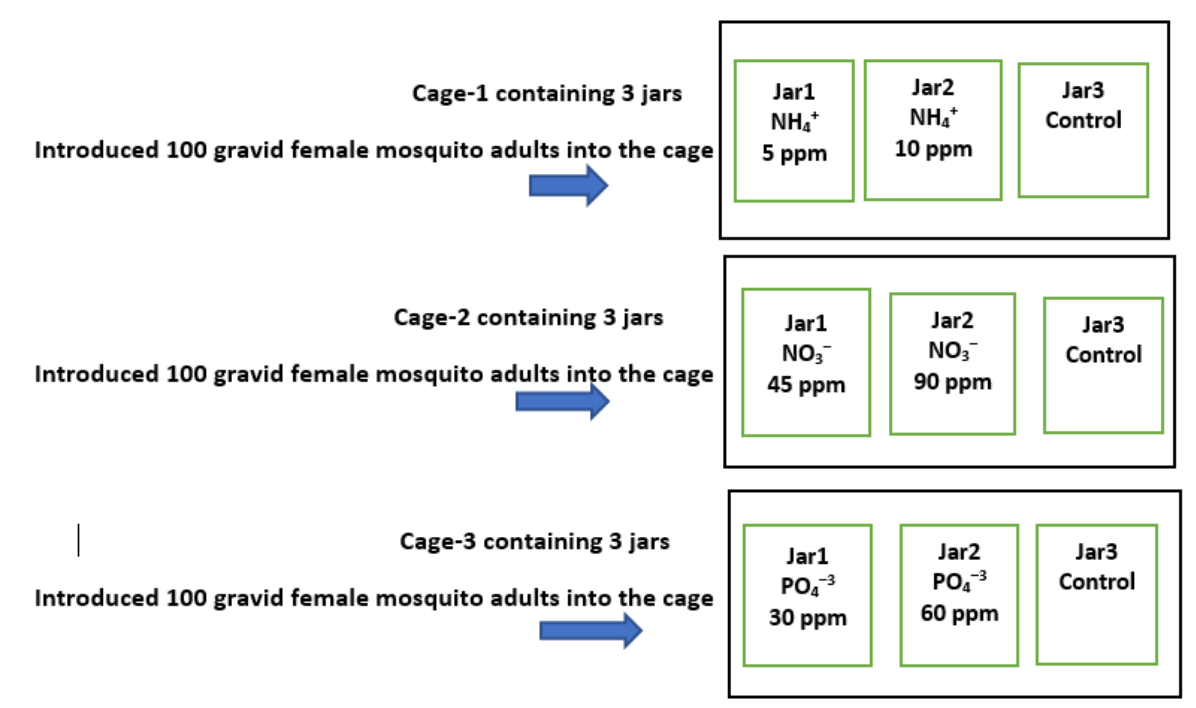

Figure 2. Schematic of experiment on the effect of inorganic nutrient pollutants on oviposition preference and egg hatching rate

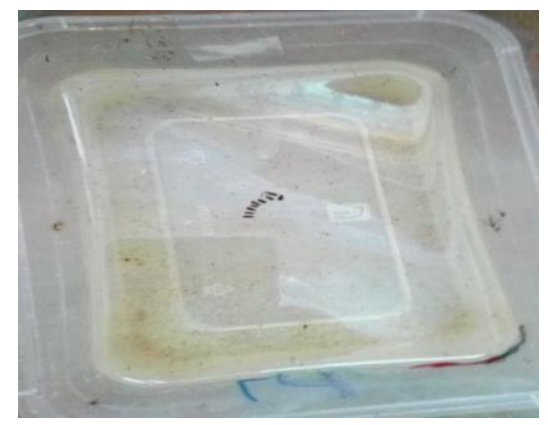

Figure 3. Egg rafts deposited by Culex quinquefasciatus during the present experiments

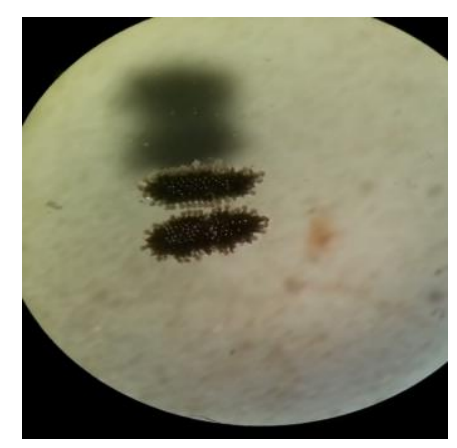

Figure 4. Microscopic picture of Culex quinquefasciatus eggs in rafts taken during the present experiments 


\section{Bioassay for effect of inorganic nutrient pollutant on larval development}

The effect of high concentration of $\mathrm{NH}_{4}^{+}(5 \mathrm{ppm}), \mathrm{NO}_{3}{ }^{-}(45 \mathrm{ppm})$ and of $\mathrm{PO}_{4}{ }^{-3}$ $(30 \mathrm{ppm})$ in water on larval development of $C x$. quinquefasciatus were also studied as these concentrations are allowable according to a compendium of standards for wastewater reuse in the Eastern Mediterranean Region (WHO, 2006). The schematic of experiment on the effect of inorganic nutrient pollutants on larval development of Cx. quinquefasciatus is shown in Figure 5. Thus $5 \mathrm{ppm}$ concentration of $\mathrm{NH}_{4}^{+}, 45 \mathrm{ppm}$ concentration of $\mathrm{NO}_{3}{ }^{-}$and $30 \mathrm{ppm}$ concentration of $\mathrm{PO}_{4}{ }^{-3}$ were prepared in three $1000 \mathrm{ml}$ polyethylene jars. The solutions were prepared from stock solutions in sieved pond water for ensuring the presence of natural communities of microflora (Noori et al., 2015). The volume of each testing solution was $500 \mathrm{ml}$. In addition, a control $1000 \mathrm{ml}$ polyethylene jar containing only $500 \mathrm{ml}$ sieved river water was also arranged. Dried leaf litter of Chenopodium album was collected along the boundary wall of University of Malakand as there was no history of pesticides application. The leaf litter was ground into powder. During this experiment, $100 \mathrm{mg}$ of leaf litter powder was added to each jar including control jar for providing source of carbon (Schletzbaum, 2013; Noori et al., 2015).

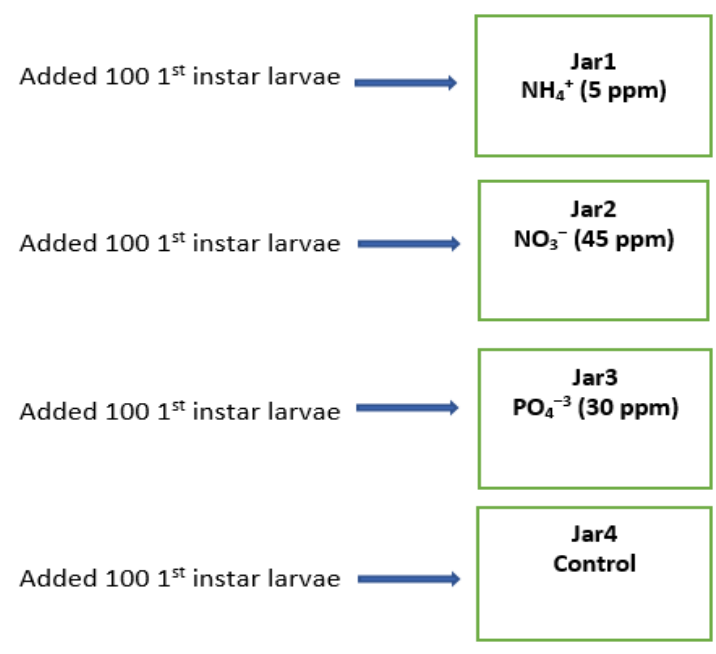

Figure 5. Schematic of experiment on the effect of inorganic nutrient pollutants on larval development of $C x$. quinquefasciatus

One hundred newly hatched $1^{\text {st }}$ instar larvae (a day after hatching) larvae of CX. quinquefasciatus from laboratory colony were transferred to each polyethylene jar. This experiment was run in four replicates. The jars were capped with gauze to prevent the escape of emerging adult mosquitoes. The jars were daily checked for the appearance of pupae and adults. The observations were continued till all the larvae or pupae in all the jars have died or emerged as adults. The effect of $\mathrm{NH}_{4}{ }^{+}, \mathrm{NO}_{3}{ }^{-}$and $\mathrm{PO}_{4}{ }^{-3}$ on time to pupation, pupation rate, time to adult emergence, adult emergence rate and female to male ratios were studied. All the mosquito adults were counted and the female to male ratio was determined by dividing the total number of female adults by the total number of male adults (Neira et al., 2014). Time to pupation or adult emergence was calculated by the following method (Kosalwat and Knight, 1987) (Eq.1): 


$$
\mathrm{T}=\sum(\mathrm{D} \times \mathrm{N}) / \sum \mathrm{N}
$$

where $\mathrm{T}$ represents the average time to pupation or adult emergence (in days), $\mathrm{D}$ represents the number of days from day zero of exposure of first instar larvae to pupation or adult emergence and $\mathrm{N}$ represents the number of pupae or adults produced. Figure 6 shows the pictures of egg, larval, pupal and adult stages of life history of Culex quinquefasciatus mosquito. The pictures have been taken in the laboratory during the present experiments.

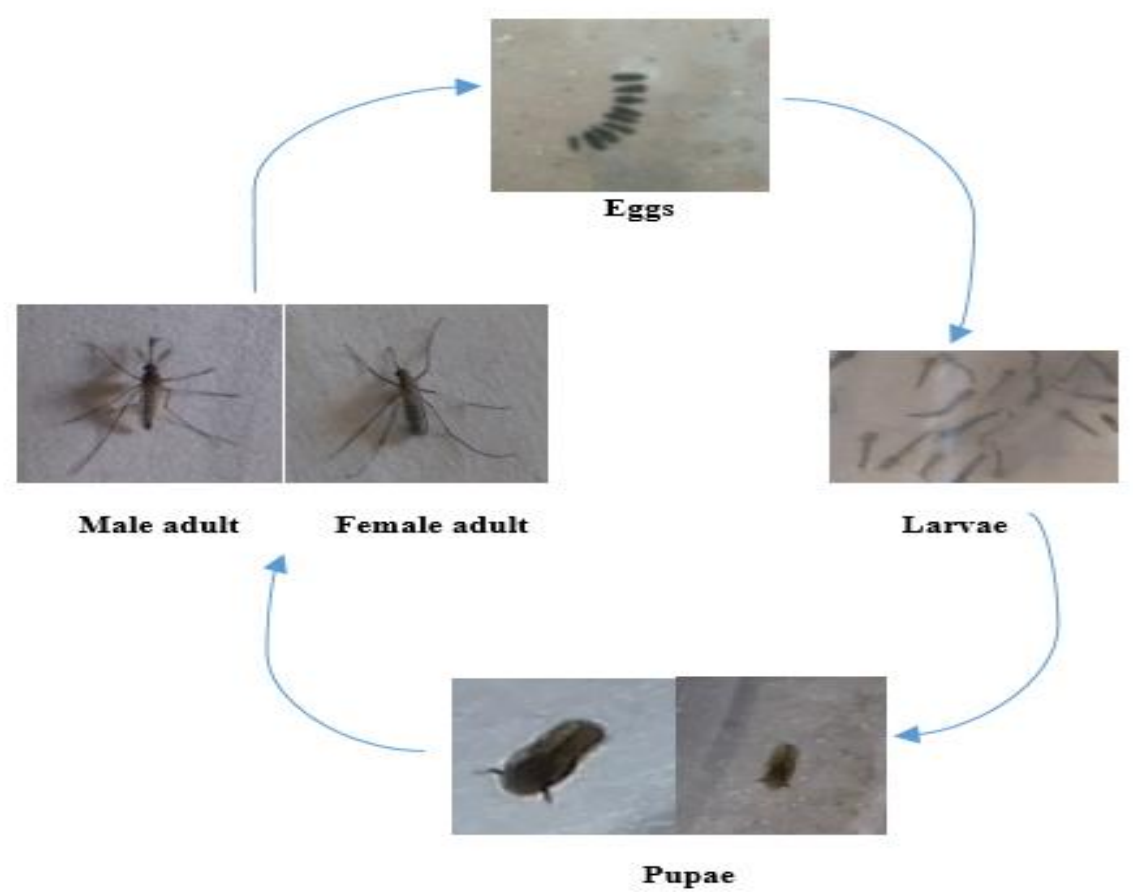

Figure 6. Picture showing the egg, larval, pupal and adult stages of life history of Culex quinquefasciatus mosquito. The figure has been produced from the pictures taken in the laboratory during the present experiments

\section{Statistical analysis}

The data was initially analyzed by normality test of Shapiro-Wilk. If the P value was less than 0.05 then the data was analyzed by Kruskal-Wallis test for comparison (Schlotzhauer and Little, 1987). When the P value in Kruskal-Wallis test was less than 0.05 then the Kruskal-Wallis test was followed by Bonferroni's post hoc test for pairwise comparison. The data was presented as the mean rank. If the value of $\mathrm{P}$ in normality test was greater than 0.05 then the data was analyzed by Dunnett's Test at $\mathrm{P}>0.05$ significance level for assessing significant difference between control and each of the treatment solution. In this case the data was presented as mean with standard error. The $\mathrm{LC}_{50}$ values were compared by $95 \%$ confidence limits overlap method (Wheeler et al., 2006). 


\section{Results}

\section{Oviposition preference of Cx. quinquefasciatus}

The effect of $\mathrm{NH}_{4}{ }^{+}(5 \mathrm{ppm}$ and $10 \mathrm{ppm}), \mathrm{NO}_{3}{ }^{-}$(45 ppm and $\left.90 \mathrm{ppm}\right)$ and $\mathrm{PO}_{4}{ }^{-3}$ (30 ppm and $60 \mathrm{ppm}$ ) on oviposition preference of $C x$. quinquefasciatus is shown in Table 1. Data is presented as means (with standard error of means) and mean ranks of egg rafts. Based on normality test of Shapiro-Wilk, the data was not normally distributed, therefore the data was analyzed by Kruskal-Wallis test at $\mathrm{P}<0.05$ significance level for determining significant difference.

During the study of effect of $\mathrm{NH}_{4}{ }^{+}$on oviposition preference, the Kruskal Wallis $\chi^{2}$ value was 6.0 and the $P$ value was 0.05 . The overall test showed significant difference in the mean ranks of egg rafts across the control and treatment containers $(5 \mathrm{ppm}$ and $10 \mathrm{ppm} \mathrm{NH}{ }_{4}{ }^{+}$solutions). The mean rank of egg rafts in $5 \mathrm{ppm} \mathrm{NH}{ }_{4}^{+}$solution container (mean rank $=8.0$ ) was significantly higher when compared to control container $(\mathrm{P}<0.05)$. The control container and $10 \mathrm{ppm} \mathrm{NH}_{4}{ }^{+}$solution container showed similar mean rank of egg rafts (mean rank $=3.5$ each).

Table 1. Effect of inorganic nutrient pollutants in water on oviposition preference of Cx. quinquefasciatus $(n=3)$

\begin{tabular}{c|c|c|c}
\hline Pollutants & Concentration & $\begin{array}{c}\text { N. of egg rafts } \\
\text { Mean } \pm \text { SE }\end{array}$ & Mean rank of egg rafts \\
\hline & Control & $1.6 \pm 0.3$ & 3.5 \\
& $5 \mathrm{ppm}$ & $7.3 \pm 0.7^{*}$ & 8 \\
Ammonium $\left(\mathrm{NH}_{4}{ }^{+}\right)$ & $10 \mathrm{ppm}$ & $1.6 \pm 0.6$ & 3 \\
& & & $\mathrm{KW}, \chi^{2}=6.0$ \\
& & & $\mathrm{P}=0.05$ \\
\hline & Control & $1.3 \pm 0.3$ & 2 \\
Nitrate $\left(\mathrm{NO}_{3}{ }^{-}\right)$ & $45 \mathrm{ppm}$ & $8.0 \pm 1.2^{*}$ & 8 \\
& $90 \mathrm{ppm}$ & $3.6 \pm 0.3$ & 5 \\
& & & $\mathrm{KW}, \chi^{2}=7.3$ \\
& & & $\mathrm{P}=0.03$ \\
\hline \multirow{3}{*}{ Phosphate $\left(\mathrm{PO}_{4}{ }^{-3}\right)$} & Control & $2.6 \pm 0.3$ & 4 \\
& $30 \mathrm{ppm}$ & $2.7 \pm 1.8^{*}$ & 8 \\
& $90 \mathrm{ppm}$ & & 3 \\
& & & $\mathrm{KW}, \chi^{2}=6$ \\
& & & $\mathrm{P}=0.049$ \\
\hline
\end{tabular}

$\mathrm{KW}$ - Kruskal-Wallis, *-.significantly different from the control at $\mathrm{P}<0.05$ significance level in Kruskal-Wallis test

During the study of effect of $\mathrm{NO}_{3}{ }^{-}$on oviposition preference, the Kruskal Wallis $\chi^{2}$ value was 7.3 and $P$ value was 0.03 . The overall test showed significant difference in mean ranks of egg rafts across the control and treatment containers $(45 \mathrm{ppm}$ and $90 \mathrm{ppm}$ $\mathrm{NO}_{3}{ }^{-}$solutions). The mean rank of egg rafts in $45 \mathrm{ppm} \mathrm{NO}_{3}{ }^{-}$solution container (mean rank $=8.0)$ was significantly higher when compared to control container (mean rank $=2)(\mathrm{P}<0.05)$. There was no significant difference $(\mathrm{P}>0.05)$ in the mean rank of $90 \mathrm{ppm} \mathrm{NO}_{3}{ }^{-}$solution container (mean rank =5) and control container (mean rank $=2$ ).

During the study of effect of $\mathrm{PO}_{4}{ }^{-3}$ on oviposition preference, the Kruskal Wallis $\chi^{2}$ value was 6.0 and $P$ value was 0.050 . The overall test showed significant difference in mean ranks of egg rafts across the control and treatment containers $(30 \mathrm{ppm}$ and $60 \mathrm{ppm}$ $\mathrm{PO}_{4}{ }^{-3}$ solutions). The mean rank of egg rafts in $30 \mathrm{ppm} \mathrm{PO}_{4}^{-3}$ solution container 
(mean rank $=8.0$ ) was significantly higher when compared to control container $($ mean rank $=4)(\mathrm{P}<0.05)$. The mean rank of egg rafts of $60 \mathrm{ppm} \mathrm{PO}_{4}^{-3}$ solution container (mean rank $=3$ ) was insignificantly lower $(\mathrm{P}>0.05)$ when compared to control container (mean rank $=4$ ).

\section{Hatching rate of Cx. quinquefasciatus}

The effect of $\mathrm{NH}_{4}{ }^{+}, \mathrm{NO}_{3}{ }^{-}$and $\mathrm{PO}_{4}^{-3}$ on hatching rate of $C x$. quinquefasciatus is shown in Table 2. Based on normality test of Shapiro-Wilk, the data was normally distributed, therefore the data was analyzed by Dunnett's Test at $\mathrm{P}<0.05$ significance level for determining significant difference between control container and each of the inorganic nutrient pollutant solution containers. Data is presented as means with standard error of means. During this study, no significant difference in egg hatching rate of $C x$. quinquefasciatus eggs was observed between the control container and any of the treatment containers $(\mathrm{P}>0.05)$.

Table 2. Effect of inorganic nutrient pollutants in water on egg hatching rate of $C x$. quinquefasciatus $(n=3)$

\begin{tabular}{c|c|c|c|c}
\hline Pollutants & Concentration $(\mathbf{p p m})$ & $\begin{array}{c}\text { Number of Eggs } \\
(\text { Mean } \pm \mathbf{S E})\end{array}$ & $\begin{array}{c}\text { Number of hatched } \\
\text { larvae (Mean } \pm \text { SE) }\end{array}$ & $\begin{array}{c}\text { Hatching rate (Mean } \\
\% \pm \mathbf{S E})\end{array}$ \\
\hline & Control & $153.3 \pm 31.8$ & $134.6 \pm 32.8$ & $86.9 \pm 4.6$ \\
Ammonium $\left(\mathrm{NH}_{4}{ }^{+}\right)$ & 5 & $724.7 \pm 68.7$ & $703.3 \pm 69.9$ & $97 \pm 0.6$ \\
& 10 & $160.0 \pm 35.1$ & $140.0 \pm 27.5$ & $88.8 \pm 3.2$ \\
& & & & $\mathrm{P}>0.05$ \\
\hline & Control & $136.3 \pm 35.4$ & $123.7 \pm 31.9$ & $96.7 \pm 1.9$ \\
Nitrate $\left(\mathrm{NO}_{3}{ }^{-}\right)$ & 45 & $780.0 \pm 118.4$ & $758.3 \pm 118.7$ & $97.03 \pm 1.3$ \\
& 90 & $353.3 \pm 34.4$ & $337.7 \pm 31.2$ & $96.6 .6 \pm 1.6$ \\
& & & & $\mathrm{P}>0.05$ \\
\hline & Control & $262.3 \pm 41.2$ & $239.3 \pm 40.01$ & $90.7 \pm 1.7$ \\
Phosphate $\left(\mathrm{PO}_{4}^{-3}\right)$ & 30 & $1417.3 \pm 123.2$ & $1320.7 \pm 115.8$ & $93.2 \pm 0.6$ \\
& 60 & $223.3 \pm 26.2$ & $212.0 \pm 29.1$ & $93.8 \pm 2.8$ \\
& & & & $\mathrm{P}>0.05$ \\
\hline
\end{tabular}

There was no significant difference $(\mathrm{P}>0.05)$ in egg hatching rate between control and treatments

\section{Larval development of $C x$. quinquefasciatus}

During the present research, the effect of $5 \mathrm{ppm} \mathrm{NH}_{4}{ }^{+}, 45 \mathrm{ppm} \mathrm{NO}_{3}{ }^{-}$and $30 \mathrm{ppm}$ $\mathrm{PO}_{4}{ }^{-3}$ on larval development of $C x$. quinquefasciatus were studied in the laboratory conditions. In addition, each container (including control) was also containing 100 grams leaf litter powder. The larval development study included the effect of above inorganic nutrient pollutants on time to pupation, pupation rate, time to adult emergence, adult emergence rate and female to male ratios. Following are the details:

\section{Time to pupation of Cx. quinquefasciatus}

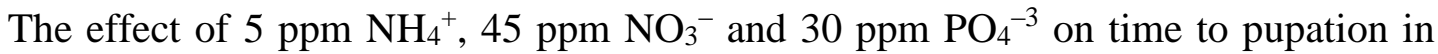
Cx. quinquefasciatus is shown in Table 3. During this study, a total of one hundred first instar larvae were exposed to each nutrient pollutant. The value of significance in normality test of Shapiro-Wilk showed that the data is normally distributed, therefore the data was analyzed by Dunnett's Test (significance level=0.05) for determining significant difference between control and each of the inorganic nutrient pollutants. Data is presented as the mean and standard error of mean of four replicates. Each 
pollutant caused a decrease in time to pupation. The minimum number of days to

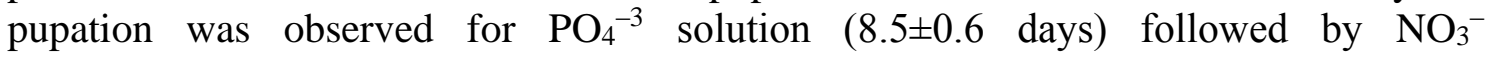


pupation between the control and $\mathrm{PO}_{4}{ }^{-3}$ solution container was significant $(\mathrm{P}<0.05)$. However, the difference between the control and the rest of the pollutants i.e., $\mathrm{NH}_{4}{ }^{+}$or $\mathrm{NO}_{3}{ }^{-}$was insignificant $(\mathrm{P}>0.05)$.

Table 3. Effect of inorganic nutrient pollutants in water on time to pupation in Cx. quinquefasciatus $(n=4)$

\begin{tabular}{|c|c|c|c|c|c|}
\hline \multirow{2}{*}{ Treatment } & \multirow{2}{*}{$\begin{array}{c}\text { Days } \\
(\text { Means } \pm \text { SE) }\end{array}$} & \multicolumn{2}{|c|}{ 95\% Confidence Intervals } & \multirow{2}{*}{ Minimum } & \multirow{2}{*}{ Maximum } \\
\hline & & Lower limit & Upper limit & & \\
\hline Control & $14.5 \pm 0.6$ & 12.4 & 16.6 & 13.0 & 16.0 \\
\hline $\begin{array}{c}\text { Ammonium } \\
\left(\mathrm{NH}_{4}{ }^{+}\right)\end{array}$ & $13.5 \pm 0.6$ & 11.4 & 15.6 & 12.0 & 15.0 \\
\hline Nitrate $\left(\mathrm{NO}_{3}^{-}\right)$ & $12.5 \pm 0.6$ & 10.4 & 14.6 & 11.0 & 14.0 \\
\hline Phosphate $\left(\mathrm{PO}_{4}^{-3}\right)$ & $8.5 \pm 0.6^{*}$ & 6.4 & 10.6 & 7.0 & 10.0 \\
\hline
\end{tabular}

*- Significantly different from the control at $\mathrm{P}<0.05$ significance level

\section{Pupation rate of $C x$. quinquefasciatus}

The effect of $\mathrm{NH}_{4}{ }^{+}(5 \mathrm{ppm}), \mathrm{NO}_{3}{ }^{-}(45 \mathrm{ppm})$ and $\mathrm{PO}_{4}{ }^{-3}$ (30 ppm) on pupation rate in Cx. quinquefasciatus is shown in Table 4. The value of significance in normality test of Shapiro-Wilk showed that the data is normally distributed, therefore the data was analyzed by Dunnett's Test (significance level $\leq 0.05$ ) for determining significant difference between control and each of the pollutants. Data is presented as the mean and standard error of mean of four replicates. Pupation rates in $\mathrm{NH}_{4}{ }^{+}$solution container $(52.0 \pm 9.9 \%)$ and $\mathrm{PO}_{4}{ }^{-3}$ solution container $(51.8 \pm 9.6 \%)$ were significantly higher $(\mathrm{P}<0.05)$ when compared to control containers $(27.0 \pm 4.9 \%)$. Pupation rate in $\mathrm{NO}_{3}{ }^{-}$ solution container $(33.0 \pm 3.4 \%)$ was insignificantly higher than pupation rate in control container $(\mathrm{P}>0.05)$.

Table 4. Effect of inorganic nutrient pollutants in water on pupation rate in Cx. quinquefasciatus $(n=4)$

\begin{tabular}{|c|c|c|c|c|c|}
\hline \multirow{2}{*}{ Treatment } & \multirow{2}{*}{$\begin{array}{c}\text { Pupation rate } \\
(\% \text { Means } \pm \text { SE) }\end{array}$} & \multicolumn{2}{|c|}{ 95\% Confidence Intervals } & \multirow{2}{*}{ Minimum } & \multirow{2}{*}{ Maximum } \\
\hline & & Lower limit & Upper limit & & \\
\hline Control & $27.0 \pm 4.9$ & 11.4 & 42.6 & 18.0 & 39.0 \\
\hline $\begin{array}{l}\text { Ammonium } \\
\left(\mathrm{NH}_{4}^{+}\right)\end{array}$ & $52.0 \pm 9.9^{*}$ & 9.6 & 94.4 & 36.0 & 70.0 \\
\hline Nitrate $\left(\mathrm{NO}_{3}-\right)$ & $33.0 \pm 3.4$ & 22.2 & 43.8 & 25.0 & 40.0 \\
\hline Phosphate $\left(\mathrm{PO}_{4}^{-3}\right)$ & $51.8 \pm 9.6^{*}$ & 21.04 & 82.5 & 30.0 & 77.0 \\
\hline Statistics & \multicolumn{5}{|c|}{$\mathrm{F}=3.2, \mathrm{DF}$ within groups $=12, \mathrm{P}<0.066$} \\
\hline
\end{tabular}

*- Significantly different from the control at $\mathrm{P}<0.05$ significance level

\section{Time to adult emergence of Cx. quinquefasciatus}

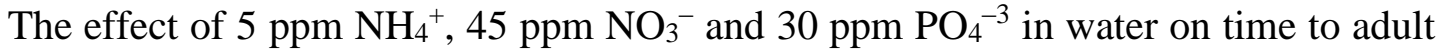
emergence in $C x$. quinquefasciatus is shown in Table 5. The value of significance in normality test of Shapiro-Wilk showed that the data is normally distributed, therefore 
the data was analyzed by Dunnett's Test (significance level=0.05) for determining significant difference between control and each of the inorganic nutrient pollutants. Data is presented as the mean and standard error of mean of four replicates. The minimum number of days to adult emergence was observed for $\mathrm{PO}_{4}{ }^{-3}$ solution (11.5 \pm 1.7 days) followed by $\mathrm{NO}_{3}{ }^{-}$(15.0 \pm 1.4 days), $\mathrm{NH}_{4}{ }^{+}$(17.0 \pm 1.4 days) and control $(18.5 \pm 2.08$ days). The difference in time to adult emergence between the control and $\mathrm{PO}_{4}^{-3}$ or $\mathrm{NO}_{3}^{-}$solution container was significant $(\mathrm{P}<0.05)$. However, the difference between the control and $\mathrm{NH}_{4}{ }^{+}$was insignificant $(\mathrm{P}>0.05)$.

Table 5. Effect of inorganic nutrient pollutants in water on time to adult emergence in Cx. quinquefasciatus $(n=4)$

\begin{tabular}{c|c|c|c|c|c}
\hline \multirow{2}{*}{ Treatment } & \multirow{2}{*}{$\begin{array}{c}\text { Days } \\
\text { (Means } \pm \text { SE) }\end{array}$} & \multicolumn{2}{|c|}{ 95\% Confidence Intervals } & \multirow{2}{*}{ Minimum } & \multirow{2}{*}{ Maximum } \\
\cline { 3 - 4 } & $18.5 \pm 2.08$ & 15.2 & 21.8 & 16.0 & 21.0 \\
\hline Control & $17.0 \pm 1.4$ & 14.7 & 19.3 & 16.0 & 19.0 \\
Ammonium & $15.0 \pm 1.4^{*}$ & 12.7 & 17.3 & 13.0 & 16.0 \\
$\left(\mathrm{NH}_{4}{ }^{+}\right)$ & $11.5 \pm 1.7^{*}$ & 8.74 & 14.3 & 10.0 & 14.0 \\
Nitrate $\left(\mathrm{NO}_{3}{ }^{-}\right)$ & \multicolumn{5}{|c}{$\mathrm{F}=12.9, \mathrm{DF}$ within groups $=12, \mathrm{P}<0.01$} \\
Phosphate $\left(\mathrm{PO}_{4}^{-3}\right)$ & \multicolumn{4}{l}{}
\end{tabular}

*- Significantly different from the control at $\mathrm{P}<0.05$ significance level

\section{Adult emergence rate of $C x$. quinquefasciatus}

The effect of $\mathrm{NH}_{4}{ }^{+}(5 \mathrm{ppm}), \mathrm{NO}_{3}{ }^{-}(45 \mathrm{ppm})$ and $\mathrm{PO}_{4}{ }^{-3}$ (30 ppm) in water on adult emergence rate in $C x$. quinquefasciatus is shown in Table 6. Data was presented as the mean and standard error of mean of emergence rates $(n=4)$. The value of significance in normality test of Shapiro-Wilk showed that the data is normally distributed, therefore the data was analyzed by Dunnett's Test (significance level $\leq 0.05$ ) for determining significant difference between control and each of the pollutant solution.

Table 6. Effect of inorganic nutrient pollutants in water on adult emergence rate of CX. quinquefasciatus $(n=4)$

\begin{tabular}{c|c|c|c|c|c}
\hline \multirow{2}{*}{ Treatment } & \multirow{2}{*}{$\begin{array}{c}\text { Emergence rate } \\
\text { (\%) (Mean } \pm \text { SE) }\end{array}$} & \multicolumn{2}{|c|}{ 95\% Confidence Intervals } & \multirow{2}{*}{ Minimum } & \multirow{2}{*}{ Maximum } \\
\cline { 3 - 4 } & Lower limit & Upper limit & & \multirow{2}{*}{40.01} \\
Ammonium & $31.5 \pm 4.4$ & 17.5 & 45.6 & 22.3 & 83.3 \\
$\left(\mathrm{NH}_{4}^{+}\right)$ & $61.9 \pm 8.7^{*}$ & 34.3 & 89.5 & 44.3 & 65.0 \\
Nitrate $\left(\mathrm{NO}_{3}{ }^{-}\right)$ & $61.5 \pm 1.9^{*}$ & 55.4 & 67.4 & 56.8 & 86.6 \\
Phosphate $\left(\mathrm{PO}_{4}^{-3}\right)$ & 20.5 & 93.8 & 32.5 & \\
Ammonium & $57.1 \pm 11.5^{*}$ & \multicolumn{3}{|c|}{$\mathrm{DF}=12, \mathrm{~F}=3.6, \mathrm{P}<0.05$} \\
$\left(\mathrm{NH}_{4}^{+}\right)$ & \multicolumn{7}{|c}{}
\end{tabular}

*- Significantly different from the control at $\mathrm{P}<0.05$ significance level

Significantly higher number of adults emerged in the $\mathrm{NH}_{4}{ }^{+}, \mathrm{NO}_{3}{ }^{-}$or $\mathrm{PO}_{4}{ }^{-3}$ solution container when compared to control container $(\mathrm{P}<0.05)$. Maximum adult emergence rates were observed in $\mathrm{NH}_{4}{ }^{+}(61.9 \pm 8.7 \%)$ and $\mathrm{NO}_{3}{ }^{-}$solution container $(61.5 \pm 1.9 \%)$. 


\section{Female to male ratio of $C x$. quinquefasciatus}

All the adults were counted and the percentage of female and male mosquitoes to the total number of adults produced were determined for each jar. Female to male ratio was obtained through dividing the number of female adult mosquitoes by the number of male adult mosquitoes. Data was presented as the mean of percentage of female and male $C x$. quinquefasciatus mosquito and mean female to male ratio (Table 7). The value of significance in normality test of Shapiro-Wilk showed that the data is distributed normally, therefore the data was analyzed by Dunnett's Test (significance level $\leq 0.05$ ) for determining significant difference between control and each of the pollutant solutions.

Table 7. Effect of inorganic nutrient pollutants in water on female to male ratio of $C x$. quinquefasciatus $(n=4)$

\begin{tabular}{c|c|c|c}
\hline Treatment & \% Female (Mean \pm SE) & \% Male (Mean \pm SE) & Female to male ratio (Mean \pm SE) \\
\hline Control & $42.9 \pm 2.3$ & $57.1 \pm 2.3$ & $0.7 \pm 0.07$ \\
Ammonium $\left(\mathrm{NH}_{4}{ }^{+}\right)$ & $52.4 \pm 0.9^{*}$ & $47.7 \pm 0.9^{*}$ & $1.1 . \pm 0.94^{*}$ \\
Nitrate $\left(\mathrm{NO}_{3}-\right)$ & $62.7 \pm 2.2^{*}$ & $37.3 \pm 2.1^{*}$ & $1.7 \pm 0.13^{*}$ \\
Phosphate $\left(\mathrm{PO}_{4}^{-3}\right)$ & $60.8 \pm 1.2^{*}$ & $39.2 \pm 1.2^{*}$ & $1.6 \pm 0.08^{*}$ \\
\hline
\end{tabular}

*- Significantly different from the control at $\mathrm{P}<0.05$ significance level

The female to male adult ratio for $\mathrm{NH}_{4}{ }^{+}, \mathrm{NO}_{3}{ }^{-}$and or $\mathrm{PO}_{4}{ }^{-3}$ solution container was significantly higher than control container $(\mathrm{P}<0.05)$. Maximum female to male ratio was observed for $\mathrm{NO}_{3}{ }^{-}$solution container that was $1.7 \pm 0.13(62.7 \pm 2.2 \%$ females, $37.3 \pm 2.1 \%$ males). After $\mathrm{NO}_{3}{ }^{-}$, maximum female to male ratio was noted for $\mathrm{PO}_{4}{ }^{-3}$ that was $1.6 \pm 0.08(60.8 \pm 1.2 \%$ females, $39.2 \pm 1.2 \%$ males $)$. The lowest female to male ratio was observed for control container that was $0.7 \pm 0.07$ ( $42.9 \pm 2.3 \%$ females, $57 \pm 2.3 \%$ males).

\section{Discussion}

During the present study, the effects of $\mathrm{NH}_{4}{ }^{+}, \mathrm{NO}_{3}{ }^{-}$and $\mathrm{PO}_{4}{ }^{-3}$ on oviposition preference, hatching rate and larval development parameters of $C x$. quinquefasciatus were studied under laboratory conditions. During the study of effect of these pollutants on oviposition preference, the effect of two environmentally realistic concentrations of $\mathrm{NH}_{4}{ }^{+}$(5 ppm and $\left.10 \mathrm{ppm}\right)$ on oviposition preference of gravid female adult $C x$. quinquefasciatus was studied. Gravid female $C x$. quinquefasciatus adults preferred the container containing $5 \mathrm{ppm} \mathrm{NH}_{4}{ }^{+}$solution but did not prefer the container containing $10 \mathrm{ppm} \mathrm{NH}{ }_{4}^{+}$solution or control container (containing only non-chlorinated tap water) (Table 1). For example, the number of egg rafts in the container containing $5 \mathrm{ppm} \mathrm{NH}_{4}{ }^{+}$was significantly higher than control container where as the number of egg rafts in the container containing $10 \mathrm{ppm} \mathrm{NH}_{4}{ }^{+}$was insignificantly lower than control container ( $\mathrm{P}>0.05)$. Nguyen et al. (2012) observed higher number of mosquito egg rafts in water containing $\mathrm{NH}_{4}{ }^{+}$above $2 \mathrm{ppm}$ when temperature was high $\left(>32^{\circ} \mathrm{C}\right)$. They observed lower number of egg rafts at the same concentration of $\mathrm{NH}_{4}{ }^{+}$when temperature was lower. During the present research, minimum temperature was $\geq 20^{\circ} \mathrm{C}$ and maximum temperature was $\leq 33^{\circ} \mathrm{C}$ in which $\mathrm{NH}_{4}{ }^{+}$at $5 \mathrm{ppm}$ concentration acted as oviposition attractant for $C x$. quinquefasciatus. During the study of effect of $\mathrm{NO}_{3}{ }^{-}$(at $45 \mathrm{ppm}$ and $90 \mathrm{ppm}$ ) on oviposition preference of $C x$. quinquefasciatus, the results 
show that gravid female $C x$. quinquefasciatus mosquito preferred water bodies with lower $\mathrm{NO}_{3}{ }^{-}$concentration (45 ppm) for oviposition. Water without $\mathrm{NO}_{3}{ }^{-}$and water with higher $\mathrm{NO}_{3}{ }^{-}$concentration $(90 \mathrm{ppm})$ were less preferred for oviposition. These results suggest that $\mathrm{NO}_{3}{ }^{-}$in water attract the gravid female $C x$. quinquefasciatus mosquito for oviposition, however water with higher $\mathrm{NO}_{3}{ }^{-}$concentration is not highly preferred for oviposition by $C x$. quinquefasciatus mosquito (Table 1). To the author knowledge, limited studies have been conducted on the effect of $\mathrm{NO}_{3}{ }^{-}$on the oviposition preference of mosquitoes. For example, Nguyen et al. (2012) studied seasonal, weather, nutrients, and conspecific presence impacts on $C x$. quinquefasciatus mosquito in combined sewage overflows. It was observed that high $\mathrm{NO}_{3}{ }^{-}$concentration i.e. $>1 \mathrm{ppm}$ is associated with decrease in the number of oviposited egg rafts. During the present research, the same trend of association of decreased number of egg rafts with high $\mathrm{NO}_{3}{ }^{-}$ concentration was observed. During the experiment of Grech and Juliano (2017), the female $C x$. restuans mosquito laid more eggs in containers having low amount of plant detritus but high concentration of total dissolved nitrogen, however after some days the gravid female $C x$. restuans preferred those containers for oviposition which were containing high amount of plant detritus but low concentration of total dissolved nitrogen and high phosphate concentration. They concluded that the concentrations of total dissolved nitrogen and phosphorus have differential effect on the oviposition preference of the gravid female $C x$. restuans, and the mosquitoes favor different nutrients in different circumstances and do not always oviposit preferentially in containers rich in plant detritus. During the study of effect of $\mathrm{PO}_{4}{ }^{-3}$ (at $30 \mathrm{ppm}$ and $60 \mathrm{ppm}$ ) on oviposition preference of $C x$. quinquefasciatus, the gravid female Cx. quinquefasciatus preferred the container for oviposition having lower $\mathrm{PO}_{4}^{-3}$ concentration $(30 \mathrm{ppm})$, however they oviposited less number of egg rafts in containers containing no $\mathrm{PO}_{4}^{-3}$ (control) or containing higher concentration of $\mathrm{PO}_{4}^{-3}(60 \mathrm{ppm})$. A breeding site rich in $\mathrm{PO}_{4}^{-3}$ and $\mathrm{NH}_{4}{ }^{+}$is an excellent larval habitat for Cx. quinquefasciatus (Nguyen et al., 2012). The $\mathrm{NH}_{4}{ }^{+}$and $\mathrm{PO}_{4}^{-3}$ promote the growth of bacteria in breeding site; the bacteria serve as food source for mosquito larvae (Beehler and Mulla, 1995; Sunish and Reuben, 2001) and attract adult gravid female mosquito for oviposition (Beehler et al., 1994). Nguyen et al. (2012) studied the effect of seasons, weather, nutrients, and conspecific presence impacts on $C x$. quinquefasciatus mosquito in combined sewage overflows. At lower $\mathrm{PO}_{4}^{-3}$ concentration, Cx. quinquefasciatus oviposited more eggs rafts, however at higher $\mathrm{PO}_{4}^{-3}$ concentration $(>10 \mathrm{ppm})$, a decrease in the number of oviposited egg rafts was observed. Similar trend was observed during the present research. Agricultural fertilizers also influence the oviposition preference of adult gravid female mosquitoes. For example, Kibuthu et al. (2016) studied the effect of sub lethal concentrations of cypermethrin, glyphosate, ammonium sulfate and diammonium phosphate on oviposition preference of Anopheles arabiensis and Culex quinquefasciatus mosquitoes. Highest number of egg rafts were observed in diammonium phosphate and ammonium sulfate treatments.

During the study of effect of inorganic nutrient pollutants on egg hatching rate, no significant difference in egg hatching rate of Cx. quinquefasciatus in $\mathrm{NH}_{4}{ }^{+}, \mathrm{NO}_{3}{ }^{-}$or $\mathrm{PO}_{4}{ }^{-3}$ solution container and control container was observed $(\mathrm{P}>0.05)$ (Table 2). To the author knowledge, there is no reported study about the effect of inorganic nutrient pollutants i.e., ammonium, nitrate and phosphate on the egg hatching rate in mosquitoes. The effect of temperature on hatching rate of mosquito eggs has been reported. For example, Oda et al. (1999) studied the effect of temperature on hatching 
rate and adult survival of $C x$. pipiens molestus and $C x$. quinquefasciatus. The egg hatching rate of $C x$. pipiens molestus became very low with rise in temperature, however no effect of temperature rises on egg hatching rate of $C x$. quinquefasciatus was observed. Yang (2008) studied the effect of site deprivation on oviposition performance and egg hatching rate of naturally blood-fed gravid Culex quinquefasciatus in the laboratory. Gravid female adults failed to form egg rafts, and egg hatching rate decreased significantly. Vitek and Livdahl (2006) compared the hatching rates of Ae. Albopictus eggs in both field and laboratory settings. The hatching rates were compared for mosquitoes exposed to regular, periodic hatch stimulation and random hatch stimulation. The hatching rate in laboratory treatments was not significantly different from the field treatments. Ezeakacha (2015) reported increase in egg hatch rate of Aedes albopictus, Aedes aegypti, Aedes triseriatus and Culex quinquefasciatus with increase in relative humidity and egg storage period.

The present study also aimed to investigate the effect of $\mathrm{NH}_{4}{ }^{+}, \mathrm{NO}_{3}{ }^{-}$, and of $\mathrm{PO}_{4}{ }^{-3}$ in water at concentration of $5 \mathrm{ppm}, 45 \mathrm{ppm}$ and $30 \mathrm{ppm}$, respectively, on larval development parameters (such as time to pupation, pupation rate, time to adult emergence, adult emergence rate and female to male ratios) of $C x$. quinquefasciatus. During this experiment, $100 \mathrm{mg}$ of leaf litter powder was added to each jar including control jar for providing source of carbon (Schletzbaum, 2013; Noori et al., 2015). During the study of the effect of $\mathrm{NH}_{4}{ }^{+}(5 \mathrm{ppm}), \mathrm{NO}_{3}{ }^{-}(45 \mathrm{ppm})$ and $\mathrm{PO}_{4}{ }^{-3}$ (30 ppm) on time to pupation, larvae of control container larvae took more days to reach pupation, however the larvae in the containers that were containing $\mathrm{NH}_{4}{ }^{+}, \mathrm{NO}_{3}{ }^{-}$or $\mathrm{PO}_{4}{ }^{-3}$ reached earlier to pupation (Table 3). Among the inorganic nutrient pollutants, $\mathrm{PO}_{4}{ }^{-3}$ caused a significant decrease in time to pupation when compared to control $(\mathrm{P}<0.05)$. To the author knowledge, very limited studies have been conducted on the effect of pollutants on time to pupation in mosquitoes. For example, Noori et al. (2015) studied the effect of $\mathrm{NH}_{4}{ }^{+}, \mathrm{NO}_{3}{ }^{-}$and $\mathrm{PO}_{4}{ }^{-3}$ in water on larval development of $C x$. quinquefasciatus. During their study, larvae that were exposed to phosphate at concentration range of $1 \mathrm{ppm}$ to $12 \mathrm{ppm}$ without leaf litter, took more time in reaching to pupation. During the present study, the phosphate solution which was also containing 100 gram of leaf litter powder, caused a decrease in time to pupation. This indicated that larvae exposed to higher phosphate concentration $(30 \mathrm{ppm})$ in presence of leaf litter reach early to pupation.

During the study of effect of $\mathrm{NH}_{4}{ }^{+}(5 \mathrm{ppm}), \mathrm{NO}_{3}{ }^{-}(45 \mathrm{ppm})$, and $\mathrm{PO}_{4}{ }^{-3}$ (30 ppm) on pupation rate of $C x$. quinquefasciatus, significantly higher number $(\mathrm{P}<0.05)$ of larvae reached to pupation in $\mathrm{NH}_{4}{ }^{+}$and $\mathrm{PO}_{4}{ }^{-3}$ solution containers when compared to control container (Table 4). These results agree with the findings of Sunish and Reuben (2001) as they reported a positive influence of ammonia nitrogen and $\mathrm{PO}_{4}{ }^{-3}$ on aquatic stages of mosquitoes. Similarly, in another study, increase in the concentration of $\mathrm{NH}_{4}{ }^{+} \mathrm{Or} \mathrm{PO}_{4}{ }^{-3}$ was associated with increase in the number of $C x$. quinquefasciatus larvae that reached to pupation (Noori et al., 2015). There was observed no significant effect of $\mathrm{NO}_{3}{ }^{-}$(at $45 \mathrm{ppm})$ on pupation rate when compared to control (P>0.05). Noori et al. (2015) also found no significant correlation between increase in $\mathrm{NO}_{3}{ }^{-}$concentration and pupation rate. The presence of $\mathrm{NH}_{4}{ }^{+}, \mathrm{NO}_{3}{ }^{-}$and $\mathrm{PO}_{4}{ }^{-3}$ accelerate the multiplication of microorganisms (Sunish and Reuben, 2001) that in turn favors the survival of Culex larvae. Paul et al. (2006) suggested that higher concentration of phosphorus in agricultural stream is associated with faster breakdown rate of leaf litter. The faster breakdown rate of leaf litter in water bodies results in multiplication of microorganisms. 
Microorganisms in mosquito breeding sites constitute the major food source of mosquito larvae.

During the study of effect of $\mathrm{NH}_{4}{ }^{+}(5 \mathrm{ppm}), \mathrm{NO}_{3}{ }^{-}(45 \mathrm{ppm})$ and $\mathrm{PO}_{4}^{-3}$ (30 ppm) in water on time to adult emergence of $C x$. quinquefasciatus, in each of the $\mathrm{NH}_{4}{ }^{+}, \mathrm{NO}_{3}{ }^{-}$ and $\mathrm{PO}_{4}{ }^{-3}$ solution containers, the larvae took less number of days to reach to adulthood than in the control container (Table 5). The first instar larvae exposed to $45 \mathrm{ppm} \mathrm{NO}_{3}{ }^{-}$ or $30{\mathrm{ppm} \mathrm{PO}_{4}}^{-3}$ solution took significantly lower $(\mathrm{P}<0.05)$ number of days in reaching to adulthood when compared to the control. The larvae exposed to $\mathrm{PO}_{4}{ }^{-3}$ took longer in reaching to adulthood. The larvae exposed to $5 \mathrm{ppm} \mathrm{NH}_{4}{ }^{+}$solution took insignificantly higher number of days in reaching to adulthood when compared to control $(\mathrm{P}>0.05)$. The early emergence of adults in $\mathrm{NH}_{4}{ }^{+}, \mathrm{NO}_{3}{ }^{-}$or $\mathrm{PO}_{4}{ }^{-3}$ solution containers (each containing $100 \mathrm{~g}$ leaf litter powder) can be attributed to increasing microbial activities (major food source of Culex larvae) (Sunish and Reuben, 2001; Paul et al., 2006).

During the study of effect of $\mathrm{NH}_{4}{ }^{+}(5 \mathrm{ppm}), \mathrm{NO}_{3}{ }^{-}(45 \mathrm{ppm})$ and $\mathrm{PO}_{4}^{-3}$ (30 ppm) in water on adult emergence rate of $C x$. quinquefasciatus, significantly higher number of adults emerged in $\mathrm{NH}_{4}{ }^{+}, \mathrm{NO}_{3}{ }^{-}$and $\mathrm{PO}_{4}{ }^{-3}$ solution containers when compared to control container $(\mathrm{P}<0.05)$ (Table 6). Noori et al. (2015) reported the boosting effect of $\mathrm{NH}_{4}{ }^{+}$, $\mathrm{NO}_{3}{ }^{-}$and $\mathrm{PO}_{4}{ }^{-3}$ on adult emergence rate of quinquefasciatus. Schletzbaum (2013) also reported the positive effect of $\mathrm{NO}_{3}{ }^{-}$concentration on adult emergence rate of Cx. pipiens. Agricultural fertilizers have also been reported for their effect on adult emergence rate of mosquitoes. For example, Kibuthu et al. (2016) observed significantly higher emergence rate of $C x$. quinquefasciatus in diammonium phosphate treatment. The high emergence rate in $\mathrm{NH}_{4}{ }^{+}, \mathrm{NO}_{3}{ }^{-}$or $\mathrm{PO}_{4}{ }^{-3}$ solution container can be attributed to increasing microbial activities (Sunish and Reuben, 2001; Paul et al., 2006).

During the study of effect of $\mathrm{NH}_{4}{ }^{+}(5 \mathrm{ppm}), \mathrm{NO}_{3}{ }^{-}(45 \mathrm{ppm})$ and $\mathrm{PO}_{4}{ }^{-3}$ (30 ppm) in water on female to male ratio of $C x$. quinquefasciatus, the female to male adult ratio for each nutrient solution container was significantly higher than control container $(\mathrm{P}<0.05)$ (Table 7). Maximum female to male ratio was observed for $\mathrm{NO}_{3}{ }^{-}$and $\mathrm{PO}_{4}{ }^{-3}$ solution container. To the author knowledge, very limited studies have been conducted on the effect of inorganic nutrient pollutants on female to male ratio in mosquitoes. For example, Noori et al. (2015) reported that high $\mathrm{NO}_{3}{ }^{-}$levels in water without leaf litter favored the development of male mosquitoes and suppresses the development of female mosquitoes. They suggested that the development of females might need more $\mathrm{PO}_{4}{ }^{-3}$ than male development. But the findings of the present study suggest that high concentration of $\mathrm{NH}_{4}{ }^{+}, \mathrm{NO}_{3}{ }^{-}$or $\mathrm{PO}_{4}{ }^{-3}$ favors the development of females. For the control container (containing only 100 grams leaf litter), the percentage of males was higher than the percentage of females $(42.9 \pm 2.3 \%$ females, $57 \pm 2.3 \%$ males).

\section{Conclusion}

It is concluded that the levels of $\mathrm{NH}_{4}{ }^{+}, \mathrm{NO}_{3}{ }^{-}$and $\mathrm{PO}_{4}{ }^{-3}$ recommended in effluents for wastewater reuse in agricultural irrigation by WHO (2006) are favorable for the survival and development of $C x$. quinquefasciatus mosquito, however higher levels of $\mathrm{NH}_{4}^{+}$, $\mathrm{NO}_{3}{ }^{-}$and $\mathrm{PO}_{4}{ }^{-3}$ are not favorable for the survival and development of this mosquito. These results help in identification of concentration ranges of the $\mathrm{NH}_{4}{ }^{+}, \mathrm{NO}_{3}{ }^{-}$and $\mathrm{PO}_{4}{ }^{-3}$ that make the larval habitat favorable for survival and reproduction of Culex mosquitoes. This could be helpful in effective control of mosquito borne diseases. 


\section{REFERENCES}

[1] Beehler, J. W., Millar, J. G., Mulla, M. S. (1994): Protein hydrolysates and associated bacterial contaminants as oviposition attractants for the mosquito Culex quinquefasciatus. - Med. Vet. Entomol. 8: 381-385.

[2] Beehler, J. W., Mulla, M. S. (1995): Effects of organic enrichment on temporal distribution and abundance of culicine egg rafts. - J. Am. Mosq. Control Assoc. 11: 167171.

[3] Camargo, J. A., Alonso, A., Salamanca, A. (2005): Nitrate toxicity to aquatic animals: a review with new data for freshwater invertebrates. - Chemosphere 58: 1255-1267.

[4] Dowling, Z., Ladeau, Sh. L., Armbruster, P., Biehler, D., Leisnham, P. T. (2013): Socioeconomic status affects mosquito (Diptera: Culicidae) larval habitat type availability and infestation level. - J. Med. Entomol. 50: 764-772.

[5] Ezeakacha, N. F. (2015): Environmental Impacts and Carry-over Effects in Complex Life Cycles: The Role of Different Life History Stages. - Ph.D. Dissertations, Graduate School of the University of Southern Mississippi.

[6] Grech, M. G., Juliano, S. A. (2017): Complex Effects of Superior Competitors and Resources on Culex restuans (Diptera: Culicidae) Oviposition. - J. Med. Entomol. $\mathrm{XX}(\mathrm{X}): 1-10$.

[7] Grubb, D. G., Guimarates, M. S., Valenica, R. (2000): Phosphate immobilizationusing an acidic typeF fly ash. - J. Hazards. Mater. 76: 217-236.

[8] Hickey, C. W., Vickers, M. L. (1994): Toxicity of Ammonia to Nine Native New Zealand freshwater Invertebrate Species. - Arch. Environ. Contain. Toxicol. 26: 292-298.

[9] Kenea, O., Balkew, M., Gebre-MichaeL, T. (2011): Environmental factors associated with larval habitats of anopheline mosquitoes (Diptera: Culicidae) in irrigation and major drainage areas in the middle course of the rift valley, central Ethiopia. - J. Vector Borne Dis. 48: 85-92.

[10] Kibuthul, T. W., Njenga, S. M., Mbugua, A. K., Muturi, E. J. (2016): Agricultural chemicals: life changer for mosquito vectors in agricultural landscapes? - Parasit Vectors 9: 500 .

[11] Kim, E., Yoo, S., Ro, H. Y., Han, H. J., Baek, Y. W., Eom, I. C., Kim, H. M., Kim, P., Choi, K. (2013): Aquatic Toxicity Assessment of Phosphate Compounds. - Environ. Health. Toxicol. 28: e2013002.

[12] Kosalwat, P., Knight, A. W. (1987): Chronic toxicity of copper to a partial life cycle of the midge, Chironomus decorus. - Arch. Environ. Contam. Toxicol. 16: 283-290.

[13] Neira, M., Lacroix, R., Cáceres, L., Kaiser, P. E., Young, J., Pineda, L., Black, L., Sosa, N., Nimmo, D., Alphey, L., McKemey, A. (2014): Estimation of Aedes aegypti (Diptera: Culicidae) population size and adult male survival in an urban area in Panama. Mem. Inst. - Oswaldo Cruz, Rio de Janeiro 109(7): 879-886.

[14] Nguyen, A. T., Williams-Newkirk, A., Kitron, U., Chaves, L. F. (2012): Seasonal Weather, Nutrients, and Conspecific Presence Impacts on the Southern House Mosquito Oviposition Dynamics in Combined Sewage Overflows. - J. Med. Entomol. 49(6): 13281338.

[15] Noori, N., Lockaby, B. G., Kalin, L. (2015): Larval development of Culex quinquefasciatus in water with low to moderatepollution levels. - Journal of Vector Ecology 40(2): 208-220.

[16] Oda, T., Uchida, K., Mori, A., Mine, M., Eshita, Y., Kurokawa, K., Kato, K., Tahara, H. (1999): Effects of high temperature on the emergence and survival of adult Culex pipiens molestus and Culex quinquefasciatus in Japan. - J. Am. Mosq. Control Assoc. 15(2): 153-156.

[17] Paul, M. J., Meyer, J. L., Couch, C. A. (2006): Leaf breakdown in streams differing in catchment land use. - Fresh w. Biol. 51: 1684-1695.

[18] Rabalais, N. N. (2002): Nitrogen in aquatic ecosystems. - Ambio. 31: 102-112. 
[19] Schletzbaum, M. A. (2013): Aqueous nitrates and larval competition alter disease risk from two urban mosquito species. - Cary Institute of Ecosystem Studies, Millbrook, NY 12545 USA.

[20] Schlotzhauer, S. D., Littel, R. C. (1987): SAS System for Elementary Statistical Analysis. - SAS Intitute Inc., Cary, NC. 416 pp.

[21] Sunish, I. P., Reuben, R. R. (2001): Factors influencing the abundance of Japanese encephalitis vectors in rice fields in India. - Med. Vet. Entomol. 15: 381-392.

[22] Tchobanoglous, G., Burton, F. L. (1991): WastewaterEngineering. - McGrow-Hill.

[23] Vitek, C. J., Livdahl, T. P. (2006): Field and Laboratory Comparison Of Hatch Rates In Aedes Albopictus (Skuse). - J. Am. Mosq. Control Assoc. 22(4): 609-614.

[24] Wetzel, R. G. (2001): Limnology. - 3rd ed. Academic Press, New York.

[25] Wheeler, M. W., Park, R. M., Bailer, A. J. (2006): Comparing median lethal concentrationvalues using confidence interval overlap or ratio tests. - Environ. Toxicol. Chem. 25: 1441-1444.

[26] WHO. (2006): A compendium of standards for wastewater reuse in the Eastern Mediterranean Region.

[27] Williams, K. A., Green, D. W. J., Pascoe, D. (1986): Studies on the acute toxicity of pollutants to fresh water macroinvertebrates. - Archives fur Hydrobiolgie 106: 61-70.

[28] Yang, P. (2008): Effect of Oviposition Site Deprivation on Oviposition Performance and Egg Hatch Rate of Naturally Blood-fed Gravid Culex quinquefasciatus (Diptera: Culicidae). - Proc. Hawaiian Entomol. Soc. 40: 51-54. 